
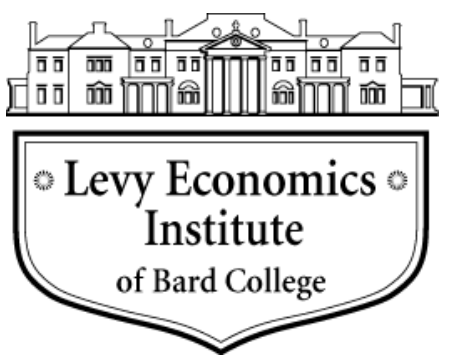

Working Paper No. 892

\title{
Understanding Financialization: Standing on the Shoulders of Minsky*
}

\author{
by \\ Charles J. Whalen \\ The Baldy Center for Law and Social Policy, SUNY Buffalo Law School
}

June 2017

* This manuscript was prepared for Financialization: New Trends and Directions of Development, an international conference in Rzeszów, Poland, June 9-10, 2017. The conference was organized by the University of Information Technology and Management in Rzeszów and the Department of Banking, Finance and Accounting at the University of Warsaw. The author is a visiting scholar at the Baldy Center for Law and Social Policy, SUNY Buffalo Law School. He thanks the conference organizers and the Association for Evolutionary Economics for making possible his participation in the event; in addition, he once again thanks Linda Whalen for careful copyediting, endless patience, and reliable feedback.

The Levy Economics Institute Working Paper Collection presents research in progress by Levy Institute scholars and conference participants. The purpose of the series is to disseminate ideas to and elicit comments from academics and professionals.

Levy Economics Institute of Bard College, founded in 1986, is a nonprofit, nonpartisan, independently funded research organization devoted to public service. Through scholarship and economic research it generates viable, effective public policy responses to important economic problems that profoundly affect the quality of life in the United States and abroad.

Levy Economics Institute

$$
\text { P.O. Box } 5000
$$

Annandale-on-Hudson, NY 12504-5000

http://www.levyinstitute.org

Copyright (C) Levy Economics Institute 2017 All rights reserved

ISSN 1547-366X 


\begin{abstract}
Since the death of Hyman Minsky in 1996, much has been written about financialization. This paper explores the issues that Minsky examined in the last decade of his life and considers their relationship to that financialization literature. Part I addresses Minsky's penetrating observations regarding what he called money manager capitalism. Part II outlines the powerful analytical framework that Minsky used to organize his thinking and that we can use to extend his work. Part III shows how Minsky's observations and framework represent a major contribution to the study of financialization. Part IV highlights two keys to Minsky's success: his treatment of economics as a grand adventure and his willingness to step beyond the world of theory. Part V concludes by providing a short recap, acknowledging formidable challenges facing scholars with a Minsky perspective, and calling attention to the glimmer of hope that offers a way forward.
\end{abstract}

Keywords: Hyman Minsky; money manager capitalism; financialization

JEL Classifications: B31; B52; G00 
In Stabilizing an Unstable Economy, Hyman P. Minsky (1986a, xiii) wrote that John Maynard Keynes provides "the shoulders of a giant upon which we can stand in order to see far and deep into the essential character of advanced capitalist economies.” Even today, Keynes remains relevant, to be sure. However, as we seek to understand and cope with financialization, we can also stand on the shoulders of Minsky.

This paper is divided into five sections. Part I summarizes and briefly reflects on Minsky’s penetrating observations regarding what he called money manager capitalism, a subject on which he focused most of his research during the decade preceding his death in 1996. Part II outlines the powerful analytical framework that Minsky used to organize his thinking and that we can use to extend his work. Part III shows how Minsky's observations and framework represent a major contribution to the study of financialization. Part IV highlights two keys to Minsky’s success: his treatment of economics as a grand adventure and his willingness to step beyond the world of theory. Part V concludes by providing a short recap as well as by acknowledging formidable academic and economic challenges and by calling attention to the glimmer of hope that offers us a way forward.

\section{MINSKY'S OBSERVATIONS ON MONEY MANAGER CAPITALISM}

Minsky is best known for his financial instability hypothesis, which suggests that the financial structure of advanced capitalist economies becomes more fragile over a period of prosperity. ${ }^{1}$ But during the last decade of his life, Minsky focused not on that hypothesis but on the emergence of what he labeled money manager capitalism (MMC). Looking primarily at the economy of the United States, Minsky observed that money managers had, since the early 1980s, replaced corporate managers as the masters of private-sector economic activity. In a series of essays, Minsky presented his observations on that development and the dangers he believed it

\footnotetext{
${ }^{1}$ See Minsky (1996, 1993, 1992a, 1990a, 1990b) and Minsky and Whalen (1996). Part I of this paper draws on the observations Minsky offered in those articles and papers.
} 
posed to the US economy - including the possibility of slower technological progress, greater economic instability, increased worker insecurity, and sharper income inequality. ${ }^{2}$

\subsection{Money Managers}

According to Minsky, MMC emerged in the 1980s and by the end of that decade the holders of the largest share of US corporate stocks and bonds were money-managing institutions—such as pension and mutual funds, bank trust departments, and the annuity arms of insurance companies — rather than individual investors. In an article published just after his death, for example, Minsky and Whalen $(1996,158)$ observed that money managers saw the fraction of US corporate equities under their control grow from 8 percent in 1950 to 60 percent in 1990; over the same period, pension funds increased their share of total business equities from less than 1 percent to almost 39 percent and their fraction of corporate debt from 13 percent to 50 percent.

As the portfolios controlled by fund managers grew, active management replaced a passive "buyand-hold" strategy. The aim of money managers - and the sole criterion by which they are judged —is maximization of the total value of investments made by fund holders. ${ }^{3}$ Thus, active management of such funds means that money managers are always "in the market.” Minsky (1990a, 69) wrote, "These funds do not buy and hold common stocks for long-term increases in dividend income: the annualized rate of return from catching a short-run swing in interest rates or stock prices can easily dominate interest or dividend income.”

With MMC taking hold, the short view replaced the long view across the economy. Money managers certainly felt the pressure of the near term—as investors' resources migrated to the most successful fund managers-but so did corporate executives. The growing influence of money managers forced business leaders to become increasingly focused on quarterly profits and the stock-market value of their corporations-in other words, on shareholder value. This pressure

\footnotetext{
${ }^{2}$ The role played by Minsky's financial instability hypothesis has evolved over time. It began (and continues to serve) as the foundation of an investment theory of business cycles (see Minsky 1975 and 1982). Then it also became an explanation for increasing financial fragility in the US economy in the decades following World War II (Minsky 1986a). Most recently, it has been presented as an alternative to the "efficient market" hypothesis of financial markets that was discredited after the global financial crisis of 2007-8 (Whalen 2013, 19).

${ }^{3}$ As Minsky wrote in 1996, "The performance of a fund and of fund managers is measured by the return on assets, which is given by the combination of dividends and interest received and the appreciation in per share value" (Minsky 1996, 363).
} 
spurred many nonfinancial corporations to scale back costly and often aging manufacturing operations, engage in mergers and acquisitions at an unprecedented pace, and turn their attention to the sorts of borrowing, investing, and lending traditionally associated with financial firms. ${ }^{4}$

The experience of General Electric (GE) is emblematic of the corporate behavior that took root as MMC emerged. When Jack Welch became the chief executive at GE in 1981, the firm was a premier US corporation- “as traditional as any large manufacturing firm in the country” (Harrison and Bluestone 1988, 36). To boost the company's earnings and stock value, Welch sought to transform the company. In the first five years, he closed a dozen plants and sold off 190 subsidiaries, including the entire small-appliances division. He also spent $\$ 6.5$ billion to acquire RCA (including its broadcasting subsidiary, NBC) and \$1.7 billion to purchase the Kidder Peabody investment bank and Employers Reinsurance, a financial services firm. The strategy achieved Welch's aims and was widely imitated. ${ }^{5}$

The emergence of MMC was also accompanied by an array of institutional innovations in the financial world. For example, since billion-dollar funds own sizable amounts of stock in individual enterprises, the growth of managed-money funds led to the development of block trading through investment banks. When a fund manager seeks to sell fund shares, investment banks buy the shares and then either find a fund willing to buy the entire lot or dispose of the shares in smaller amounts over time (Minsky 1990a, 70).

Other financial innovations arose in large part because fund managers had outgrown portfolios of high-quality stocks and bonds. Always on the lookout for higher returns, money managers provided an eager market for new, specialized instruments such as securitized mortgages, creditcard receivables, and junk bonds (Minsky 1992a, 32). The needs of money managers also spurred the development of program trading and portfolio insurance, observed Minsky (1990b, 213).

\footnotetext{
${ }^{4}$ Minsky's observations on what the emergence of MMC meant for corporations (see, for example, Minsky [1996] and Minsky and Whalen [1996]) were reinforced by the work of other economists writing in the 1980s, including Niggle (1988 and 1986) and Harrison and Bluestone (1988).

${ }^{5}$ The brief discussion of GE in this paper is drawn from Lueck (1985) and Harrison and Bluestone (1988, 36-37), but Jack Welch's transformation of the company was widely covered by journalists and extensively analyzed by academics.
} 
MMC may have originated in the United States, but Minsky understood from the start that it had global significance. In a conference paper delivered in 1988, for example, Minsky wrote that MMC was already "international in both the funds and the assets in the funds” and that it would continue to grow internationally. "As managed funds grow," he added, "we should expect a world in which international portfolio diversification is much more prevalent than it is to date" (Minsky 1990a, 71). ${ }^{6}$

\subsection{Technological Progress}

Minsky worried that MMC came with a number of dangers, including the possibility that technological progress and industrial innovation would stagnate. He offered two reasons: technological development usually demands a longer time horizon than that which drives money managers; and MMC often leaves corporations without sufficient financial resources for such development. Thus, from the perspective of what he called the "capital development of the economy,” Minsky feared that the financial evolution that produced MMC “may well have been retrograde” (Minsky 1993, 113).

Minsky argued that money-fund managers do not see themselves as guardians of the economy's capital development, adding that this made them fundamentally different from the earlier leaders of finance admired by Joseph Schumpeter. Their emphasis, Minsky continued, is instead on trading profits, which he characterized as “the quick turn of the speculator.” In fact, Minsky suggested that Keynes's famous remark about speculation and enterprise is especially relevant for MMC:

Speculators do no harm as bubbles on a steady stream of enterprise. But the position is serious when enterprise becomes the bubble on a whirlpool of speculation. When the capital development of a country becomes the by-product of the activities of a casino, the job is likely to be ill-done (Keynes, quoted in Minsky 1993, 111-12).

\footnotetext{
${ }^{6}$ In a paper delivered in Budapest in 1990, Minsky wrote: “Multinational corporations are of lessening importance; multinational portfolios are of increasing importance” (Minsky 1990b, 211).
} 
For Minsky, MMC made the financial structure of the US economy look increasingly like a casino—and pressured nonfinancial enterprises to choose diversification over modernization. ${ }^{7}$

Minsky also argued that innovation would be sluggish because companies in the era of MMC are often saddled with a high level of indebtedness, making it difficult for them to invest from internal funds. Often, such indebtedness came from a leveraged buyout or other restructuring. Under MMC, Minsky explained, money managers have an incentive to sell their shares to support takeovers and financial restructuring initiatives that promise to boost near-term portfolio value; they also tend to be the buyers of bonds issued to finance such reorganizations (Minsky 1990a, 70). ${ }^{8}$

In short, Minsky wrote that the main purpose of those now in control of corporations (money managers) was no longer to make profits from production and trade. Rather, the purpose had become giving value to stockholders by assuring that the liabilities of corporations are fully priced in the financial market. In practice, that means "pledging a very high proportion of prospective cash flows to satisfy debt liabilities"-and not worrying whether there is much left for capital development (Minsky 1993, 112).

\subsection{Economic Instability}

Increased economic instability is another danger Minsky associated with MMC. To be sure, Minsky understood that the financial system had already become increasingly fragile in the three decades before MMC emerged in the 1980s. In fact, Stabilizing an Unstable Economy discusses that process in detail: corporations took on more and more debt; banks expanded off-balancesheet operations; and "fringe banking" grew relative to the rest of the financial system (Minsky 1986a). ${ }^{9}$ But MMC added to the increased instability in important ways, Minsky argued: it

\footnotetext{
${ }^{7}$ As Minsky wrote in 1992, "The emergence of MMC means that the financing of the capital development of the economy has taken a back seat to the quest for short run total returns” (Minsky 1992a, 32).

${ }^{8}$ In a paper written for a conference held in 1990, Minsky $(1993,111)$ wrote: "Given the tax laws and the way markets capitalized income streams in the 1980s, the total market valuation (value of equity shares plus bonds) of a highly indebted firm was typically greater than the market valuation of a more conservatively financed firm."

${ }^{9}$ Minsky's "fringe banking" includes lending by finance companies, corporate issues of commercial paper, and banks outside the Federal Reserve System. The concept is similar, but not identical, to "shadow banking." For a recent discussion of shadow banking, see Nesvetailova (2014).
} 
increased the possibility of a market panic; it fueled securitization; and it threatened to trigger an economic crisis that only coordinated international action would resolve.

Minsky's concern that money managers and block traders might contribute to the panic selling of equities was rooted in historical observation. In a paper written for a conference held in 1988, Minsky observed that position-taking by block traders (and the short-term financing provided to them by big banks) disappeared in the stock-market crash of October 1987 and that intervention by the Federal Reserve was needed to stabilize the market. "More than ever," he wrote, "the profit sustaining effect of government expenditures [...] together with prompt Federal Reserve intervention is required for aggregate stability” (Minsky 1990a, 70-71).

In the same paper, Minsky (1990a, 71) argued there is a "symbiotic relation between the growth of securitization and of managed money." ${ }^{10}$ Having recently returned from a conference convened (in May 1987) by the Federal Reserve Bank of Chicago, Minsky summed up the main takeaway as follows: "That which can be securitized will be securitized” (Minsky 1990a, 70). But Minsky was ahead of the curve: A year before the conference he had written not only that securitization was poised to be "the wave of the future" but also that it came with the risk of an asset sell-off, falling asset prices, and "contagion reactions” on an international scale (Minsky 1986b). ${ }^{11}$ When mortgage securitization turned a real-estate bust into a global financial nightmare in 2007, Minsky— who had been dead for over a decade— gained considerable notoriety and was even the subject of a front-page story in The Wall Street Journal (Lahart 2007). ${ }^{12}$

\footnotetext{
${ }^{10}$ According to Minsky: "Money managers are a large part of the market for securitized instruments. Sophisticated instruments can be created that mete out the cash flow from a corpus of assets with given cash flow properties to various claimants - the essence of securitization - in a way that is tailor-made to suit the objectives of a particular fund” (Minsky 1990a, 71).

${ }^{11}$ Securitization put financial regulators in a tough spot, Minsky argued: "The growth of securitization means that, even as the power and authority of the regulators are attenuated, the scope and dimensions of their task increase" (Minsky 1986b, 14).

${ }^{12}$ According to Minsky, “An easier filter for financing ruled after securitization was developed than before.” The reason was simple: originators and underwriters walked away from the deal with net income and no recourse from the owners. "All that was required for the originators to earn their stipend was skill avoiding obvious fraud and in structuring the package” (Minsky 1992b, 23).
} 
Minsky wasn't merely concerned that MMC could trigger an international economic crisis; he was also worried that it was no longer possible for the United States to act "as the guardian angel for stability in the world economy” (Minsky 1986b, 15). Rather, he argued, “as the countries that are involved in MMC increase, an international division of responsibility for maintaining global aggregate profits will be necessary” (Minsky 1990a, 70). A year before his death, Minsky wrote: “Global financial integration is likely to characterize the next era of expansive capitalism. The problem of finance that will emerge is whether the financial and fiscal control and support institutions of national governments can contain both the consequences of global financial fragility and an international debt deflation” (Minsky 1995, 93).

\subsection{Worker Insecurity and Income Inequality}

Minsky saw rising worker insecurity and income inequality as the flipside of MMC. He considered it no surprise that insecurity and inequality increased as money managers gained influence over the economy. In fact, Minsky offered two reasons for the trend: at the enterprise level, MMC pressured employers to cut labor costs; and at the macroeconomic level, workers were hurt by a grossly overvalued dollar attributable in large part to the portfolio choices of money managers.

In 1996, Minsky discussed the influence of money managers on the employment relationship within corporations. He wrote: "There is an almost chronic need to downsize overhead and to seek the lowest possible variable cost.” As a result, workers’ benefits were slashed or eliminated, concessions were demanded from unions, jobs were outsourced and off-shored, and many longstanding assurances of continued employment vanished (Minsky 1996, 363).

Later that same year, Minsky and Whalen (1996) offered a further examination of this aspect of MMC by outlining some of the dimensions of growing worker insecurity and inequality. For example, their essay mentions widespread income stagnation, longer job searches, increased family dependence on multiple job holdings, and explosive growth in part-time and temporary work. It also quotes Stephen Roach, chief economist at Morgan Stanley: "Recovery or not, the 1990s are still all about downsizing, longer workdays, white-collar shock and relatively limited 
opportunities for new employment” (quoted in Minsky and Whalen 1996, 160). ${ }^{13}$ Under MMC, all types of labor were increasingly seen by corporations as a "spot market” commodity—just another cost to be minimized.

Minsky also saw a macroeconomic dimension to rising worker insecurity. MMC "has rendered obsolete the view that trade patterns determine the short-run movement of exchange rates," he argued (Minsky 1990a, 71). Elaborating on this in another essay, Minsky wrote: "Because of the links among financial markets brought about by portfolio movements, [...] portfolio choices of money managers drive exchange rates; the balance and terms of trade can change out of proportion to changes in relative production efficiencies” (Minsky 1990b, 211).

Then he connected the exchange rate to problems faced by US workers: "Much of America's industrial decline of the early 1980s was a creation of a grossly overvalued dollar that resulted from interest rate differentials, safe haven portfolio choices towards the dollar, and speculative momentum rather than due to a sudden deterioration of America's comparative production costs” (Minsky 1990b, 211). ${ }^{14}$

\subsection{Minsky’s Observations in Retrospect}

Although Minsky’s observations were made more than two decades ago, he identified trends and dangers that continue to shape economic life in the United States and the global economy. Consider the following, for example.

\footnotetext{
${ }^{13}$ Two notes are warranted. First, while Roach mentions "white-collar shock," it is worth recalling that blue-collar shock had already been widespread for at least a decade, owing to plant closings at facilities making a variety of products including steel, automobiles, consumer electronics, and textiles. Second, Minsky and Whalen (1996) cite a companion piece by Whalen (1996) that provides details on divergent trends across household income quintiles and on the rising gap between worker and executive salaries.

${ }^{14}$ In another essay, Minsky noted that dollar-denominated debts in the global economy also contribute to worker insecurity in the United States. Because of the magnitude of such debts, the stability of the international financial system requires that the United States maintain both a sizable trade deficit and long-term capital exports, he argued:
}

The unemployment and industrial disruption in the rust belt are not due solely to "industrial" inefficiencies. They largely are due to exchange rate patterns that emerged as market mechanisms "tried" to attain balance of trade positions which enable debt burdens to be carried [...]. United States workers may lose jobs so that Brazilian debts to Swiss bankers that manage accounts for Arab interests can be validated. (Minsky 1986c, 4 and 9) 
The share of US corporate equities held directly by households has continued its post-World War II decline, and money managers now control about two-thirds of the domestic equity market (see figure 1). ${ }^{15}$ To be sure, a significant share of today's fund assets are passively managed (in the form of index funds, for example), but most—70 percent—are still actively managed (Miller 2016). Moreover, shareholder value is now widely recognized as driving corporate governancealong with the complementary strategic orientation of "downsize and distribute," which has replaced “retain and reinvest” (Lazonick and O’Sullivan 2000).

Even before the global financial crisis of 2007-8, the International Monetary Fund (2006) observed a global trend away from traditional banking (sometimes called "lend and hold") and toward financing through markets and new forms of intermediation such as securitization (often called "originate and distribute"). All of this was anticipated by Minsky (1990a, 70-71), who wrote - in 1988 - that "the 1950s and 1960s pattern of continuing bank and bank borrower relations is now obsolete." 16

The global financial crisis underscored the worldwide reach of MMC, the associated risk of macroeconomic instability, and the value of international policy coordination. ${ }^{17}$ In addition, over the past few years it has become impossible for scholars, policymakers, and reporters to ignore the realities of worker insecurity and widening income inequality in the United States and other advanced industrial nations. ${ }^{18}$

\footnotetext{
${ }^{15}$ Although the holdings of pension funds have decreased somewhat since the year 2000 (consistent with the movement of corporations away from defined-benefit pensions), holdings of mutual funds, hedge funds, and exchange traded funds have largely taken their place (Ro 2015).

${ }^{16}$ For more on "lend and hold" vs. "originate and distribute," see Kregel (2008).

${ }^{17}$ For a Minskian perspective on globalization and the need for international action, see Wray (2011); for other perspectives, see Feenstra and Taylor (2014).

${ }^{18}$ While much has been written about worker insecurity since Donald Trump's electoral victory in 2016-see, for example, Levin-Waldman (2017) - Hacker (2006) is still worth reading. Also noteworthy is the 700-page book on inequality by Piketty (2014), which was a recent bestseller despite its considerable heft.
} 


\section{MINSKY'S THEORY OF CAPITALIST DEVELOPMENT}

Of course, Minsky did not just leave behind perceptive observations that still resonate. He also left us an analytical framework that not only organizes and provides a context for those observations but also enables us to extend his work. That framework yielded his theory of US capitalist development - a theory rooted in an evolutionary and institutionally oriented view of the economy, fashioned with an acute awareness of the central role that finance plays in economic life and centered on the interaction of finance and industry.

\subsection{Evolution and Institutions}

The crucial foundation of Minsky's theory is his conception of the economy. Minsky argued that the underlying conception of economic life in conventional economics is characterized by endogenous stability: the economic system is believed to be inherently stable, or at least selfregulating, and business cycles and other economic dynamics are caused by exogenous disturbances. Instead, Minsky stood on the shoulders of Karl Marx, Wesley Mitchell, Schumpeter, Michael Kalecki, and Keynes, all of whom viewed business cycles—and economic dynamics in general—as largely endogenous.

In particular, Minsky saw cycles and other economic dynamics as an inherent part of capitalist economic life—a natural consequence of self-interested behavior taking place in complex systems of economic and financial relations. Moreover, from Minsky's perspective, the disruptiveness of a bout of instability —indeed, the complexion of all economic outcomesdepends on the aptness of institutions and policy interventions (Ferri and Minsky 1992).

In other words, Minsky did not begin by assuming the inherent efficiency of markets and the validity of a laissez-faire stance toward economic policy. Instead, his starting point was evolutionary and institutionally focused thinking about the economy. Then he took that starting point and used it to analyze "the path of development of an accumulating capitalist economy through historical time” (Minsky 1986d, 285). ${ }^{19}$

\footnotetext{
${ }^{19}$ Minsky (1986d) — a paper prepared for a conference that convened in 1983—contains what I believe is his first (albeit brief) discussion of the emergence of MMC.
} 


\subsection{The Centrality of Finance}

The economists who inspired Minsky shared an appreciation of the central role that credit and finance play in a capitalist economy. ${ }^{20}$ "Because credit is essential to the process of development, a theory of economic development needs to integrate money into its basic formulation," wrote Minsky (1990a, 55). And, in another essay, he added: "The in-place financial structure is a central determinant of the behavior of a capitalist economy” (Minsky 1993, 106).

While scholars have long recognized Schumpeterian forces of creation and destruction when looking at products, production, and even industrial organization, Minsky — who studied with Schumpeter at Harvard — emphasized that Schumpeter also gave attention to changes in financial systems. As a result, Minsky's theory stressed that financial markets evolve not only in response to the profit-driven demands of business leaders and individual investors but also as a result of the profit-seeking entrepreneurialism of financial firms. According to Minsky, "Nowhere is evolution, change and Schumpeterian entrepreneurship more evident than in banking and finance and nowhere is the drive for profits more clearly the factor making for change” (Minsky 1993, 106).

Minsky was explicit about the centrality of finance in his evolutionary theory. He wrote: "To understand the short-term dynamics of business cycles and the longer-term evolution of economies it is necessary to understand the financing relations that rule, and how the profitseeking activities of businessmen, bankers, and portfolio mangers lead to the evolution of financial structures” (Minsky 1993, 106). In fact, while conventional economics puts consumer choice in the driver's seat, Minsky rejected that in favor of the vision (conception of economic life) of Schumpeter and Keynes: "Consumer sovereignty is subordinated to the vision of entrepreneurs and the critical analysis of bankers in determining the path of the economy" (Minsky 1993, 107).

\footnotetext{
${ }^{20}$ In addition to Schumpeter, Keynes, Mitchell, and the other economists mentioned above, Henry C. Simons also inspired Minsky. Simons's view of the monetary-financial process and its role in economic life was much closer to that of Keynes and the institutionalists than to more recent "Chicago School” economists, argued Minsky (1982, 7173).
} 


\subsection{The Interaction of Finance and Industry}

In an essay titled "Money and Crisis in Schumpeter and Keynes," Minsky (1986e) suggested that The General Theory was written because the Great Depression led Keynes to see a need to move beyond the economics of his previous books. I suspect it was written at a time when Minsky was feeling the same way about his own books. In fact, Minsky, who until that time had relied almost exclusively on Keynes for insight, practically says just that: "Further progress in understanding capitalism may very well depend upon integrating Schumpeter's insights with regard to the dynamics of a capitalist process and the role of innovative entrepreneurs into an analytical framework that in its essential properties is Keynesian” (Minsky 1986e, 113).

“Money and Crisis in Schumpeter and Keynes” marks a turning point in Minsky’s research— toward integrating Schumpeter (and Mitchell) and Keynes. From Keynes, Minsky gained an understanding of how business cycles emerge as existing financial structures become more fragile over time. From Schumpeter, Minsky gained insight into how those structures evolvetaking on new dimensions and reshaping the economy in the process. The result of Minsky's integration was his sketch of a long-term theory of US economic development, a theory focused on the interaction of finance and industry.

Elements of Minsky's theory are discussed in a number of articles and working papers. ${ }^{21}$ Taken together, they form an analysis that traces US capitalism through five stages: commercial capitalism (1607-1813); industrial capitalism (1813-90); finance capitalism (1890-1933); managerial capitalism (1933-82); and MMC (1982-present). ${ }^{22}$ While providing a detailed account of the stages and the evolution of the economy from one stage to another is beyond the scope of this paper, we can identify and briefly trace changes along some of the important dimensions that Minsky highlighted. ${ }^{23}$

\footnotetext{
${ }^{21}$ For the most important essays in which Minsky addressed elements of his theory of capitalist development, see Minsky (1996, 1993, 1992a, 1990a, 1990b) and Minsky and Whalen (1996).

${ }^{22}$ In my own writings, I prefer to use the term "banker capitalism” (a term I borrow from John R. Commons) for what Minsky called "finance capitalism" (a term often traced to Rudolf Hilferding). Since "finance" is an activity taking place at all stages, I find it best to avoid using the term to label a particular stage. However, I use Minsky’s term here, in part because it is often used by other economists - including some who are cited in this paper.

${ }^{23}$ For further discussion of Minsky's stages and the evolution from one stage to another, see Whalen (2008a, 2008b, 2001).
} 
What follows is a brief look at four dimensions of industry and finance that Minsky discussed when examining US economic development. Changes over time along each of these dimensions help to distinguish one stage from another (see also table 1):

- The distinctive activity being financed evolved from the trading or processing of goods, to industrial expansion (acquisition of factories and machines), to industrial consolidation (trusts and merger), to macroeconomic growth and stability, and-in MMC— to corporate reorganization or restructuring designed to boost shareholder value.

- The pivotal source of financing evolved from the merchant bank (though internal finance was also important), to the investment bank (in both the industrial and finance stages, though such banking was more centralized in the latter stage), to the central bank (though internal finance was once again important), and —in MMC—-to managed-money funds. (Moreover, “originate and distribute” became a key feature of financing in MMC, as previously discussed.)

- The fundamental entity being financed evolved from a proprietorship or partnership, to an industrial corporation, to a combined corporation, to the private sector financed through the central banking system (but the conglomerate was the dominant corporate form), and —in MMC—-to the international corporation.

- The locus of power was initially dispersed among merchants and bankers, but it then shifted to investment bankers during industrial and finance capitalism, to corporate managers (who assumed macroeconomic stabilization by government), and eventually—in MMC—-to money-fund managers.

\subsection{Extending Minsky's Theory}

By leaving behind a framework for analysis and not just insightful observations, Minsky allows us to stand on his shoulders to extend his theory of development and more clearly understand economic reality. The extensions of Minsky's theory to date have taken a variety of shapes, including efforts to: enrich his analysis of stages; apply his framework to shed light on 
subsequent developments in the United States and the global economy; and build on his work to understand developing and emerging economies. A few examples of each are briefly discussed.

Some extensions of Minsky’s theory of US capitalist development have sought mainly to enrich or flesh out Minsky’s analysis. An early effort on my own part was published in 1997. It focused primarily on how MMC and the spread of worker insecurity—-the end of "shared prosperity" were two sides of the same coin (Whalen 1997). A second article, published in late 2001, explained the framework and then offered a thumbnail sketch of the stages and their evolution (Whalen 2001). A third article returned to the interaction between MMC and insecurity and updated it to the eve of the global financial crisis (Whalen 2008a).

William Van Lear has also fleshed out Minsky’s theory. For example, his book A Populist Challenge to Corporate Capitalism enriches the Minskian theory in the course of exploring whether the economy's evolution accords with fundamental American principles, which Van Lear identifies as a commitment to liberty, representation, property, and enterprise. Among his conclusions: the corporation has evolved along a path inconsistent with these principles (Van Lear 2002). More recently, Van Lear and Sisk (2010) further fleshed out Minsky’s theory in an article that explores how MMC is similar to the earlier era of finance capitalism.

Since Minsky’s death, a number of economists have used his analytical framework to shed light on subsequent developments in the United States and the global economy. In 2002, for example, Zalewski (2002) looked at the rise of retirement insecurity in the age of MMC; Rima (2002) brought into the picture information technology, venture capital, further globalization, and NASDAQ trading; and my own essay considered developments including the technology-driven boom that preceded the dot-com collapse (Whalen 2002). Minsky’s framework has also been employed more recently to examine rising income inequality (Zalewski and Whalen 2010) and, of course, the global financial crisis (Whalen 2010; Wray 2010; Tymoigne and Wray 2014). ${ }^{24}$

\footnotetext{
${ }^{24}$ A further extension of Minsky is offered by Brown (2008) and Todorova (2009), who draw on aspects of his framework to examine consumer debt and the household sector.
} 
A growing number of economists have also built on Minsky's work to understand developing and emerging economies. They include Ventimiglia and Tavasci (2010), who explored how MMC has increased financial fragility in developing countries (such as Chile) that are primarily dependent on one commodity. Another contribution to this literature is Liang (2011), who examined the flow of capital into emerging market economies from countries where MMC prevails, highlighting the effects on financial-system development, market volatility, and macroeconomic policy. Her bottom-line conclusion would have come as no surprise to Minsky: global money managers require greater regulatory scrutiny.

\section{UNDERSTANDING FINANCIALIZATION}

Minsky's observations and framework represent a major contribution to the study of financialization. Scholars often observe that the financialization literature lacks cohesion, but a number of strands can be identified. Elements of Minsky's work represent a contribution to them all—and in some cases, he anticipated much of the work done in recent decades.

\subsection{Three Strands}

Natascha Van der Zwan (2014) identifies three strands in the financialization literature. One strand equates financialization with the ascendancy of shareholder value as the driver of corporate behavior. A key contribution to that literature is Lazonick and O'Sullivan (2000). As we have seen above, Minsky anticipated much of the literature that highlights the emergence of a shareholder value orientation and that examines its tremendous economic significance.

A second strand equates financialization with a regime of accumulation - that is, with a new stage of capitalist growth and development. In contrast to the strand of research emphasizing shareholder value, which focuses on microeconomic activity, this second strand focuses on the macroeconomic sphere. In this strand, financialization in recent decades is seen as "a pattern of accumulation in which profit making occurs increasingly through financial channels rather than through trade and commodity production” (Krippner 2005, 181). An important early contribution 
to this literature is Arrighi (1994), though the tradition can be traced back further, including Aglietta (1979).

Minsky's theory of capitalist development parallels the financialization work done by Arrighi and other scholars working in the macro sphere. Both lines of research place the US and global economic developments of the past few decades in the context of a broader sweep of historyand both put the interaction of finance and industry at the heart of their analysis. Minsky’s work warrants recognition as part of this strand of financialization, not just for the observations on MMC but also for the analytical framework that connects those observations and allows us to integrate them with our own findings as the economy continues to evolve.

A third strand of financialization highlighted by Van der Zwan is the financialization of everyday life. According to Van der Zwan (2014, 111), this strand involves studies that concern themselves with the rise of the citizen as investor. That research includes "a cultural perspective on financialization, particularly with regard to the encroachment of finance into the realms of everyday life.”

Although there are certainly aspects of this third strand that reach far beyond the work of Minsky, there is also some noteworthy overlap. To be sure, Minsky’s scholarship doesn’t contribute much to the work of researchers who examine how financial literacy campaigns affect the way ordinary people see themselves and their role in the economy and society. But also of interest to scholars working in this strand are the material outcomes of economic life for the broader population (Van der Zwan 2014, 111)_something often overlooked in the other strands. Since a focus on material outcomes relates directly to the connection that Minsky made between MMC and worker insecurity, it seems reasonable to conclude that Minsky offered a contribution of substance to this strand as well as to the others.

\subsection{Additional Strands and Definitions}

Gretta Krippner $(2005,181)$ offers three additional strands of the financialization literature. One equates financialization with the rise of mutual funds and the explosive growth in financial trading that followed. Another uses financialization to describe a shift from bank-based, 
relational financing to market-based, arms-length financing as well as to increased reliance on new forms of intermediation such as securitization. A third strand uses the term to refer to an upsurge in the economic and political power of those who derive their income from financial investments (that is, the rentier class). Minsky seldom addressed the political power associated with the rise of MMC, but there is no question that he anticipated much of the recent scholarship on each of the other aspects of financialization identified by Krippner.

Reflecting on the many strands of financialization research, Gerald Epstein (2005) fashioned a broad definition for his edited volume Financialization and the World Economy: "Financialization means the increasing role of financial motives, financial markets, financial actors, and financial institutions in the operation of the domestic and international economies.” Building on that definition, Thomas Palley argued at the end of 2007 that the principal effects of financialization are to: "elevate the significance of the financial sector relative to the real sector; transfer income from the real sector to the financial sector; and contribute to increased income inequality and wage stagnation” (Palley 2007, 3). In light of the observations discussed in earlier sections of this paper, it seems certain that Minsky would have seen Palley’s list as a good summary of the effects of MMC but with one huge omission: increased economic instability and the likelihood of a severe, global downturn. By mid-2008, that omission was apparent to economists and policymakers worldwide.

\section{UNDERSTANDING MINSKY}

It is often said that Minsky was prescient about many things, including money managers, shareholder value, banking, securitization, and, of course, instability.

I attribute his ability to see what so many others missed and to peer so far into the future to two features of Minsky’s outlook: he treated economics as a grand adventure, and he was willing, indeed eager, to step outside the world of theory and come into contact with the world of economic practice. 


\subsection{Economics as a Grand Adventure}

In the early 1990s, a small batch of Minsky’s papers addressed his interactions with Schumpeter at Harvard in the period 1946-49. Minsky described learning that Schumpeter would sit alone during office hours: the graduate students of the time “did not take Schumpeter seriously," he observed.

The prevailing ethic was careerist. The working postulate [...] was not only that big thinking was in the past, but, in truth, that it was not worth doing [...]. In the prevailing view, economics was now a normal science, not a grand adventure, and therefore Schumpeter was irrelevant. (Minsky 1992c, 362, n. 2)

But Minsky looked at things differently. So he joined Schumpeter in his study—often accompanied by classmate Paulo Sylos Labini. Schumpeter encouraged them to develop their own style and follow their own vision. ${ }^{25}$ The message from Schumpeter: "Normal science was too easy” (Minsky 1993, 103).

Minsky's vision (conception of the economy) was influenced by his time with Schumpeter, but he actually acquired the notion of economics as a grand adventure during his years as an undergraduate at the University of Chicago (1937-41). In 1985, Minsky wrote about those years, stressing that economics was presented as part of the study of society:

Economic history, political science, sociology, anthropology and economics were part of an integrated sequence aimed at understanding modern society [...]. If I had my way, the standard American course in economics would be eliminated and economics would be introduced in the context of social sciences and history. The current American way of teaching economics leads to economists who are well trained but poorly educated. (Minsky 1985, 214)

Minsky’s vision was also shaped by events in the world around him while living in Chicago. Memorable events included local labor strikes (during one strike in 1937, police shot and killed ten unarmed demonstrators) and a swirl of domestic and international developments, including the trials and errors of the New Deal and war in Europe. He also attended many political talks

\footnotetext{
${ }^{25}$ According to Schumpeter, every theory rests on a theorist's view (vision) of the basic features of society and what is-and is not-important for understanding economic life (Minsky 1992c, 365).
} 
and lectures, including a short course offered by Oscar Lange, which "made economics both interesting and important” (Minsky 1985, 213-15). ${ }^{26}$

Another influence on Minsky was his service during and after World War II, which included work in the Manpower Division of the Office of Military Government in Berlin in 1946. His division head was David Saposs, a well-known labor economist and student of John R.

Commons. "The experience in Germany—and the interactions with Saposs-impressed upon me the importance of the specific institutions and historical circumstances upon what happens in the world.” In fact, that experience reinforced what Minsky learned from Paul Douglas at Chicagonamely, that any formal analytical tool explains little of what happens in the world and "to be useful analytical tools have to be embedded in an understanding of the institutions, traditions, and legalities of the market” (Minsky 1985, 212 and 216).

After the global financial crisis, a number of prominent academics were asked how economists were caught flat-footed by the meltdown. Franklin Allen of the Wharton School argued the problem was that such an event was unimaginable to economists: "It's not just that they missed it; they positively denied it would happen” (Knowledge@Wharton 2009). Similarly, Wilem Buiter, chief economist at Citigroup in London, wrote that most economists had adopted an efficient-market perspective, resulting in theories "that not only did not allow questions about insolvency and illiquidity to be answered; they did not allow such questions to be asked" (Buiter 2009). In contrast, Minsky devoted his career to asking such questions - they were part of his attempt to understand the world around him, part of his vision, part of his grand adventure.

\subsection{Beyond the World of Theory}

Minsky's ability to see what other people overlooked cannot be attributed to his vision alone. Another important part of his perceptiveness came from a willingness-indeed, eagerness - to step beyond the world of theory and come into regular contact with the world of practice. An early example of this is suggested by a Harvard-era recollection that he offered in an interview for a festschrift celebrating his career. As one would expect, Minsky mentioned the influence of

\footnotetext{
${ }^{26}$ Minsky also writes about spending a spring vacation (in 1939) in Memphis, Tennessee, where he worked with organizers from the Southern Tenant Farmers Union. "This experience transcended the abstract student concerns with American racism and poverty” (Minsky 1985, 217).
} 
Schumpeter, but he also mentioned John H. Williams, who served as vice president of research at the Federal Reserve Bank of New York as well as a Harvard professor and administrator (Papadimitriou 1992, 20).

After tenure and promotion at Brown University, Minsky moved to the University of California, Berkeley, and collaborated with acquaintances from Harvard who worked nearby at the Bank of America (BoA). Together, they arranged funding for seminars and lectures that fostered interaction between the bank's staff and Berkeley faculty and students. At that time, BoA was the largest bank in the United States and had invented the VISA card, then known as Bankamericard. “The interchange of ideas in these seminars helped fashion Hy's ideas about institutional innovation in banking,” reports Dimitri Papadimitriou (1992, 22), who interviewed Minsky for the festschrift.

Minsky later moved to Washington University in St. Louis and began an association with the Mark Twain Banks. When offers from other universities eventually came in, Washington University remained the more attractive option because of Minsky’s relationship with the banks. Asked by Papadimitriou to identify his most important intellectual debs, Minsky responded:

It's hard to say. Certainly [Henry] Simons, Lange, and Schumpeter were important, but generally I believe we are all products of our environment. The involvement with the Bank of America staff, and later with the Mark Twain Bancshares was also significant in the development of my ideas. (quoted in Papadimitriou 1992, 25)

Minsky’s engagement continued when he moved from Washington University to the Levy Economics Institute in the early 1990s. There, he participated in regular seminars and conferences that drew practitioners as well as scholars from around the world. He also began each day by reading The Wall Street Journal, Financial Times, and other newspapers. Minsky understood what was happening in the economy, especially with respect to money and finance, because he was, to the very end, a voracious student of how it actually functioned. 


\section{CONCLUSION: A RECAP, CHALLENGES, AND A GLIMMER OF HOPE}

For most of his career, Minsky stood on the shoulders of Keynes to understand financial markets and business cycles. Then, in the final decade of his life, he stood on the shoulders of Schumpeter and Keynes to understand the longer-term trends in the US economy. The result was a series of publications in which Minsky offered penetrating observations on the emergence and spread of what he called money manager capitalism. His essays from that period also sketch out a powerful analytical framework that Minsky used to organize his thinking and offer a theory of US capitalist development.

Today, we can stand on Minsky’s shoulders. Since his death, a literature on financialization has developed and rapidly expanded. This paper has shown that Minsky's work represents a major contribution to that literature, touching on virtually all strands of contemporary financialization research. Standing on the shoulders of Minsky, we can update his observations, apply his framework, and extend his theory. In the process, we can explore new trends, identify and embark on new directions for research, and-equally important-enhance public understanding of what's happening in the economy.

\subsection{Difficult Times}

These are difficult times in the academy for scholars with a Minskian perspective. Minsky’s formidable powers of economic observation surfaced because he treated economics as a grand adventure into matters that were as important as they were interesting. Then he honed those powers, leaving behind an extraordinary legacy of insight and analysis, because he was willing to step beyond the world of theory and come into regular contact with the world of economic practice. Today, however, there is little room for any of that-it was the road less traveled in his time, and is an even more precarious and desolate way in ours. ${ }^{27}$ Despite the not-too-distant experience of a global financial crisis, much of the economics profession remains in denial about the need to change (Parramore 2016; Chakrabortty 2013; Davies 2012).

\footnotetext{
${ }^{27}$ Writing in 1985, Minsky observed that he came of age in a different academic era and offered one possible reason for the change: "[At Chicago], there was relatively little of the intellectual posturing that now characterizes much of economics; subsidized research and consultancies were rare” (Minsky 1985, 212).
} 
These are challenging times outside academia as well. The US economy has been stuck in low gear for so long that secular stagnation is again part of the profession's vocabulary. Working families in the United States continue to bear the burden of four decades of earnings stagnation and income inequality (Gould 2017 and 2015). ${ }^{28}$ And money manager capitalism, a.k.a. financialization, remains entrenched-despite contributing not only to macro and labor problems across the nation but also to increased economic and political tensions in Europe and elsewhere. $^{29}$

\subsection{Hope}

Still, all is not lost. As Minsky stressed, economic systems are not natural systems: an economy is a social organization created by a combination of legislation and evolutionary processes of invention and innovation: "Policy can change both the details and the overall character of the economy, and the shaping of economic policy involves both a definition of goals and an awareness that actual economic processes depend on economic and social institutions” (Minsky 1986a, 7).

Policy_at times intentionally and at other times inadvertently_helped to create and reinforce money manager capitalism. ${ }^{30}$ Policy can also scale it back, tame it, or even replace it. Besides, as Minsky often said, capitalism “comes in as many varieties as Heinz has of pickles,” so we certainly have plenty of options from which to choose. ${ }^{31}$

Standing on the shoulders of Minsky, we better understand financialization. This includes the dispiriting realization that financialization represents "an essential ingredient in the accentuation of the predatory nature of current American capitalism” (Minsky 1996, 363). But we also catch a

\footnotetext{
${ }^{28}$ Economic challenges in the United States are likely to become more difficult in the coming years owing to the ongoing aging of the baby-boom generation.

${ }^{29}$ For an examination of how financialization has contributed to slower economic growth as well as greater instability and inequality, see Tomaskovic-Devy, Lin, and Meyers (2015).

${ }^{30}$ Minsky seldom mentioned the role played by government in the emergence and spread of MMC, but some references and a few complementary articles are listed in Whalen (2008a, 286). Minsky had more to say about how to turn policy in a more progressive direction; see, for example, Minsky (1996) and Minsky and Whalen (1996).

${ }^{31}$ Minsky was also not terrified by the word "socialism." In fact, he thought the label actually had little meaning since some brands of socialism have a lot more in common with certain types of capitalism than with other brands of socialism (and vice versa). He was, however, deeply committed to individual liberty, democracy, social justice, and a humane economy (Minsky 1985, 221; Minsky 1986a, 9-10, 293).
} 
glimmer of hope in the realization that there is nothing natural about the economic system and nothing inevitable about our economic future. The task ahead is to use our improved understanding to chart a course toward a future in which the economy is not only more robust and stable, but also more humane. 


\section{REFERENCES}

Aglietta, Michael. 1979. A Theory of Capitalist Regulation: The US Experience. London: Verso.

Arrighi, Giovanni. 1994. The Long Twentieth Century: Money, Power and the Origins of Our Times. London: Verso.

Brown, Christopher. 2008. Inequality, Consumer Credit and the Saving Puzzle. Cheltenham, UK: Edward Elgar.

Buiter, Wilem. 2009. "The Unfortunate Uselessness of Most 'State of the Art' Academic Monetary Economics.” Voxeu.org, March 6. Last accessed May 27, 2017, via https://tinyurl.com/5ty5q6f.

Chakrabortty, Aditya. 2013. "Mainstream Economics is in Denial: The World Has Changed.” The Guardian, October 2. https://tinyurl.com/y9mr3ful.

Davies, Howard. 2012. “Economics In Denial.” Social Europe, August 24. Last accessed May 27, 2017, via https://tinyurl.com/y8t6ggd7.

Epstein, Gerald. 2005. "Introduction.” In Gerald Epstein (ed.), Financialization and the World Economy. Cheltenham, UK: Edward Elgar.

Feenstra, Robert C., and Alan M. Taylor (eds.). 2014. Globalization in an Age of Crisis: Multilateral Economic Cooperation in the Twenty-First Century. Chicago: University of Chicago Press.

Ferri, Piero, and Hyman Minsky. 1992. "Market Processes and Thwarting Systems.” Structural Change and Economic Dynamics 3(1): 79-91.

Gould, Elise. 2015. “2014 Continues a 35-Year Trend of Broad-Based Wage Stagnation.” EPI Issue Brief No. 393.Washington, DC: Economic Policy Institute. Last accessed March 27, 2017, via https://tinyurl.com/o8hhnv9.

— 2017. "The State of American Wages, 2016.” Economic Policy Institute Report, March 9. Last accessed March 27, 2017, via https://tinyurl.com/gof7b33.

Hacker, Jacob. 2006. The Great Risk Shift. New York: Oxford University Press

Harrison, Bennett, and Barry Bluestone. 1988. The Great U-Turn: Corporate Restructuring and the Polarization of America. New York: Basic Books.

International Monetary Fund. 2006. World Economic Outlook: Financial Systems and Economic Cycles. Washington, DC: International Monetary Fund. Accessed May 24, 2017, via https://tinyurl.com/chxvfp2. 
Knowledge@Wharton. 2009. "Why Economists Failed to Predict the Financial Crisis.” Knowledge@Wharton, May 13. Last accessed May 27, 2017, via https://tinyurl.com/ycbkuwca.

Kregel, Jan. 2008. "Minsky's Cushions of Safety: Systemic Risk and the Crisis in the US Subprime Mortgage Market.” Public Policy Brief, No. 93. Annandale-on-Hudson, NY: Levy Economics Institute of Bard College.

Krippner, Greta R. 2005. "The Financialization of the American Economy.” Socio-Economic Review 3(May): 173-208.

Lahart, Justin. 2007. "In Time of Tumult, Obscure Economist Gains Currency.” The Wall Street Journal, August 18.

Lazonick, William, and Mary O’Sullivan. 2000. "Maximizing Shareholder Value: A New Ideology for Corporate Governance.” Economy and Society 29(February): 13-35.

Levin-Waldman, Oren. 2017. “The Politics of Distraction.” Yonkers Tribune, May 24. Accessed May 24, 2017, via https://tinyurl.com/mefjxeb.

Liang, Yan. 2011. "Money Manager Capitalism, Capital Flows, and Development in Emerging Market Economies: A Post-Keynesian Institutionalist Analysis.” In Charles J. Whalen (ed.), Financial Instability and Economic Security after the Great Recession. Cheltenham, UK: Edward Elgar.

Lueck, Thomas J. 1985. “Why Jack Welch is Changing G.E.” The New York Times, May 5. Accessed May 24, 2017, via https://tinyurl.com/mqqd5t6.

Miller, G.E. 2016. “70\% of Fund Assets are Still Active Vs. Passive.” 20Something Finance, October 7. Accessed: May 24, 2017, via https://tinyurl.com/maf5452.

Minsky, Hyman. 1975. John Maynard Keynes. New York: Columbia University Press.

—. 1982. Can "It" Happen Again? Essays in Instability and Finance. Armonk, NY: M.E. Sharpe.

—. 1985. "Beginnings.” Banca Nazionale del Lavoro 38(September): 211-21.

—. 1986a. Stabilizing an Unstable Economy. New Haven, CT: Yale University Press. 1986b. “Global Consequences of Financial Deregulation.” Marcus Wallenberg Papers on International Finance 2(October): 1-19.

_. 1986c. "Conflict and Interdependence in a Multipolar World." Studies in Banking and Finance 4: 3-22. 
- 1986d. "The Crises of 1983 and the Prospects for Advanced Capitalist Economies." In Suzanne W. Helburn and David F. Bramhall (eds.), Marx, Schumpeter, and Keynes: A Centenary Celebration of Dissent. Armonk, NY: M.E. Sharpe.

- 1986e. "Money and Crisis in Schumpeter and Keynes.” In H.-J. Wagener and J.W. Drukker (eds.), The Economic Law of Motion in Modern Society: A Marx-KeynesSchumpeter Centennial. Cambridge, UK: Cambridge University Press.

_. 1990a. “Schumpeter: Finance and Evolution.” In Arnold Heertje and Mark Perlman (eds.), Evolving Technology and Market Structure: Studies in Schumpeterian Economics. Ann Arbor, MI: The University of Michigan Press.

1990b. "Money Manager Capitalism, Fiscal Independence, and International Monetary Reconstruction.” In M. Szabo-Pelosczi (ed.), The Future of the Global Economic and Monetary System. Budapest: Institute for World Economics of the Hungarian Academy of Sciences.

_. 1992a "Reconstituting the United States’ Financial Structure: Some Fundamental Issues.” Levy Institute Working Paper No. 69, January. Annandale-on-Hudson, NY: Levy Economics Institute of Bard College.

1992b. "The Capital Development of the Economy and the Structure of Financial Institutions.” Levy Institute Working Paper No. 72, January. Annandale-on-Hudson, NY: Levy Economics Institute of Bard College.

—. 1992c. “Commentary.” In Frederic M. Scherer and Mark Perlman (eds.), Entrepreneurship, Technological Innovation, and Economic Growth: Studies in the Schumpeterian Tradition. Ann Arbor, MI: University of Michigan Press.

1993. "Schumpeter and Finance.” In Salvatore Biasco, Alessandro Roncaglia, and Michele Salvati (eds.), Market and Institutions in Economic Development: Essays in Honour of Paulo Sylos Labini. New York: St. Martin’s Press.

- 1995. "Longer Waves in Financial Relations: Financial Factors in the More Severe Depressions II.” Journal of Economic Issues 29(March 1995): 83-96.

— 1996. “Uncertainty and the Institutional Structure of Capitalist Economies.” Journal of Economic Issues 30(June): 357-68.

Minsky, Hyman, and Charles J. Whalen. 1996. "Economic Insecurity and the Institutional Prerequisites for Successful Capitalism.” Journal of Post Keynesian Economics 19(Winter): 155-70.

Nesvetailova, Anastasia. 2014. "Shadow Banking and the Political Economy of Financial Innovation.” Unpublished manuscript. Available at: https://tinyurl.com/y9w3dpqj. 
Niggle, Christopher J. 1986. "Financial Innovation and the Distinction Between Financial and Industrial Capital.” Journal of Economic Issues 20(June): 374-82.

- 1988. “The Increasing Importance of Financial Capital in the US Economy.” Journal of Economic Issues 28(June): 581-98.

Palley, Thomas. 2007. “Financialization: What It Is and Why It Matters.” Levy Institute Working Paper No. 525, December. Annandale-on-Hudson, NY: Levy Economics Institute of Bard College.

Papadimitriou, Dimitri B. 1992. “Minsky on Himself.” In Steven Fazzari and Dimitri B. Papadimitriou (eds.), Financial Conditions and Macroeconomic Performance: Essays in Honor of Hyman P. Minsky. Armonk, NY: M.E. Sharpe.

Parramore, Lynn. 2016. “Are Economists in Denial About What’s Driving the Inequality Train Wreck?” Institute for New Economic Thinking, January 27. Last accessed May 27, 2017, via https://tinyurl.com/ycyuveng.

Piketty, Thomas. 2014. Capital in the Twenty-First Century. Cambridge, MA: Belknap Press.

Rima, Ingrid H. 2002. "Venture Capitalist Financing: Contemporary Foundations for Minsky’s 'Wall Street’ Perspective.” Journal of Economic Issues 36(June): 407-14.

Ro, Sam. 2015. “Here’s Who Owns the Stock Market.” Business Insider, January 9. Accessed May 23, 2017, via https://tinyurl.com/melch9x.

Todorova, Zdravka. 2009. Money and Households in a Capitalist Economy. Cheltenham, UK: Edward Elgar.

Tomaskovic-Devy, Donald, Ken-Hou Lin, and Nathan Meyers. 2015. "Did Financialization Reduce Economic Growth?” Socio-Economic Review 13(May): 525-48.

Tymoigne, Eric, and L. Randall Wray. 2014. The Rise and Fall of Money Manager Capitalism. New York: Routledge.

Van der Zwan, Natascha. 2014. "Making Sense of Financialization.” Socio-Economic Review 12(January): 99-129.

Van Lear, William. 2002. A Populist Challenge to Corporate Capitalism. River Edge, NJ: World Scientific.

Van Lear, William, and James Sisk. 2010. "Financial Crisis and Economic Stability: A Comparison Between Finance Capitalism and Money Manager Capitalism.” Journal of Economic Issues 44(September): 779-93. 
Ventimiglia, Luigi, and Daniela Tavasci. 2010. "Money Manager Capitalism in Primary Commodity-Dependent Developing Economies.” In Daniela Tavasci and Jan Toporowski (eds.), Minsky, Crisis and Development. Basingstoke, UK: Palgrave Macmillan.

Whalen, Charles J. 1996. “The Age of Anxiety: Erosion of the American Dream.” USA Today (magazine), September: 14-16.

. 1997. "Money Manager Capitalism and the End of Shared Prosperity.” Journal of Economic Issues 31(June): 517-25.

—. 2001. "Integrating Schumpeter and Keynes: Hyman Minsky’s Theory of Capitalist Development.” Journal of Economic Issues 35(December): 805-23.

_. 2002. “Money Manager Capitalism: Still Here, But Not Quite as Expected.” Journal of Economic Issues 36(June): 401-06.

—. 2008a. "Post-Keynesian Institutionalism and the Anxious Society.” In Sandra S. Batie and Nicholas Mercuro (eds.), Alternative Institutional Structures: Evolution and Impact. New York: Routledge.

—. 2008b. "John R. Commons and John Maynard Keynes on Economic History and Policy: The 1920s and Today.” Journal of Economic Issues 42(March): 225-42.

—. 2010. “A Minsky Perspective on the Global Recession of 2009.” In Daniela Tavasci and Jan Toporowski (eds.), Minsky, Crisis and Development. Basingstoke, UK: Palgrave Macmillan.

_. 2013. "Post-Keynesian Institutionalism after the Great Recession.” European Journal of Economics and Economic Policies: Intervention 10(April): 12-27.

Wray, L. Randall. 2010. "Minsky, the Global Money-Manager Crisis, and the Return of Big Government.” In Steven Kates (ed.), Macroeconomic Theory and Its Failings. Cheltenham, UK: Edward Elgar.

— 2011. "Minsky’s Money Manger Capitalism and the Global Financial Crisis.” Levy Institute Working Paper No. 661, March. Annandale-on-Hudson, NY: Levy Economics Institute of Bard College.

Zalewski, David A. 2002. "Retirement Insecurity in the Age of Money Manager Capitalism.” Journal of Economic Issues 36(June): 349-55.

Zalewski, David A., and Charles J. Whalen. 2010. "Financialization and Income Inequality: A Post-Keynesian Institutional Analysis.” Journal of Economic Issues 44(September): 75777. 
Figure 1. Ownership of the US Equity Market since 1945 (Holdings through 3Q 2014)

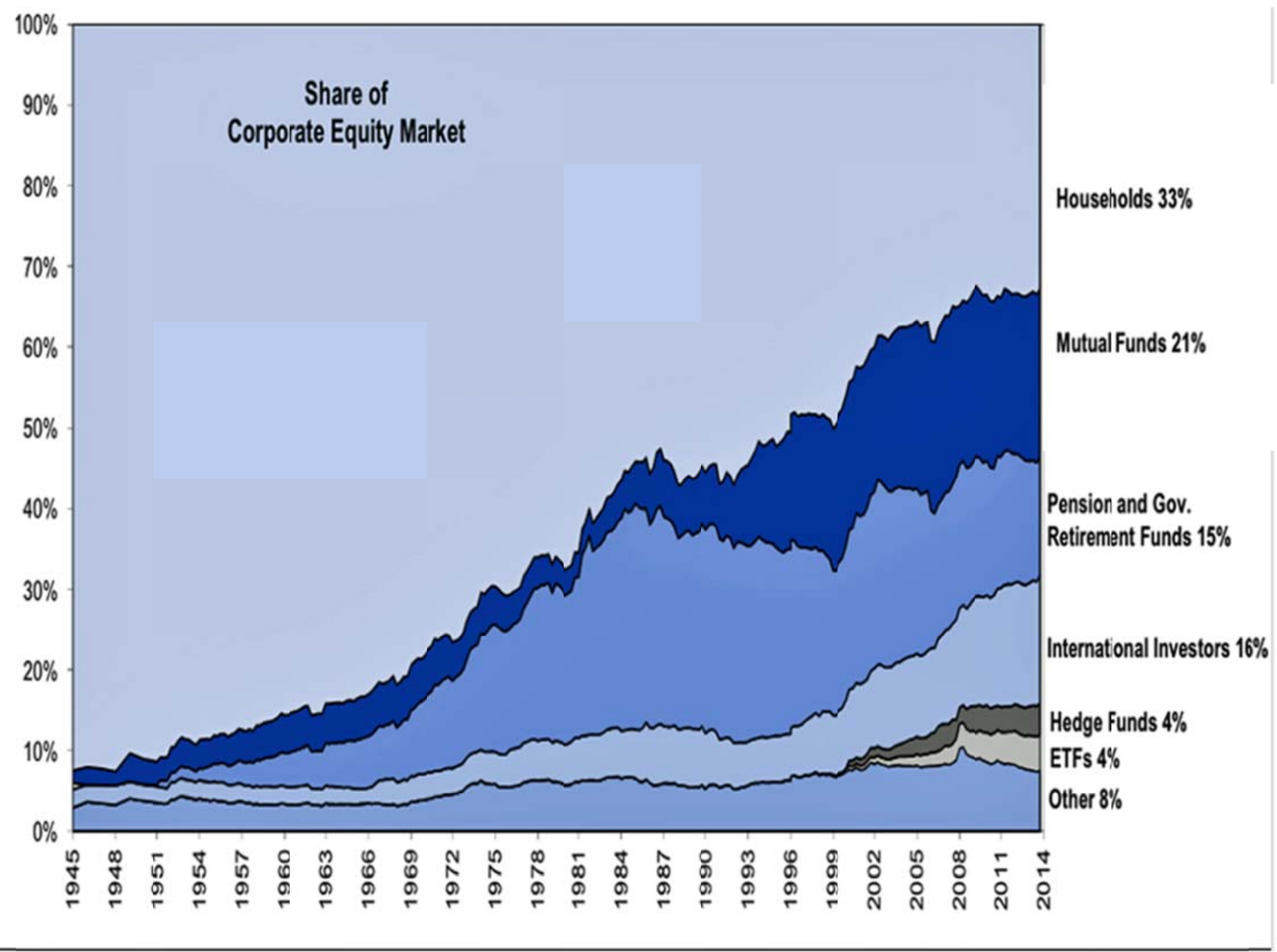

Source: Federal Reserve Board and Goldman Sachs Global Investment Research, Reproduced from Ro (2015). 


\section{Table 1. Minsky's Stages of Capitalist Development}

Commercial
Capitalism
$(1607-1813)$

$\begin{array}{ll}\text { Distinctive } & \text { Trading, transporting or } \\ \text { Activity } & \text { processing goods; inve }\end{array}$

$\begin{array}{ll}\text { Distinctive } & \text { Trading, transporting or } \\ \text { Activity } & \text { processing goods; inventory }\end{array}$

Financed acquisition and storage

Pivotal Source

Merchant bank (also internal financing)

Fundamental Proprietorships \& Entity/Enterprise partnerships Financed

\section{Finance \\ Capitalism \\ (1890-1933)}

Managerial
Capitalism
(1933-1982)

\section{Money-Manager \\ Capitalism \\ (1982-present)}

\section{Industrial}

expansion

rustment bank

Industrial

corporation
Industrial consolidation
Macroeconomic growth \& stability

nvestment bank

Combined corporation
Strategies to boost corporate stock-market values and profits $\begin{array}{cc}\text { Central bank } & \text { Institutional investment } \\ \text { (and internal financing) } & \text { funds }\end{array}$

Private sector International (financed through the corporation banking sector: conglomerates dominate the business structure)

Investment bankers Investment bankers

Corporate managers

Money-fund managers Macroeconomic stabilization
by government; industry
coordination by business executives

\section{Expertise in finance \& accounting}

Source: Whalen (2001) 